\title{
The Influence of Human Development Index Components on Economic Growth in DIY
}

\author{
Agnes Ratih Ari \\ Faculty of Economics and Business \\ Janabadra University \\ Yogyakarta, Indonesia \\ agnes@janabadra.ac.id
}

\author{
Danny Wibowo \\ Surabaya Schools of Economics of \\ Indonesia \\ Surabaya, Indonesia \\ dannywibowo.stiesia.ac.id
}

\author{
Kusmaryati Dwi Rahayu \\ Faculty of Economic and Business \\ Janabadra University \\ Yogyakarta, Indonesia \\ kusmaryati@janabadra.ac.id
}

\begin{abstract}
The old development perspective which focuses on physical development, has shifted towards the human paradigm as the main key to development. Improving the quality of human capital has a major influence on increasing a country's economic growth. This study aims to analyze the effect of the components of the Human Development Index on economic growth in the Special Region of Yogyakarta. The components of the human development index in this study include Life Expectancy, Average Length of School and Per Capita Expenditures. This research uses quantitative methods. The type of data used is secondary data with cross section 5 district / city panel data and time series for 10 years, from 2009-2018. The analytical tool used is panel data with the Common Effect model. The results showed that life expectancy had a negative and not significant effect on economic growth, the average length of school had a positive and significant effect on economic growth, per capita expenditure had a negative and significant effect on economic growth and life expectancy, average length of schooling, and per capita expenditure jointly influence economic growth.
\end{abstract}

\section{Keywords: Human Development Inde, Economic Growth, life expectancy, per capita expenditure, panel data}

\section{INTRODUCTION}

The old development point of view which emphasizes physical development and focuses on high economic growth, has experienced a paradigm shift in which humans are the main component of development [1]. Human development is the main purpose of the development of acountry [2] As a key component in development, humans are faced with many choices in their welfare. Thus, the main factor in development is the quality of man himself. [3]. The Human Development Index (HDI) provides an explanation of how people can access development results, namely in obtaining income, health, education and so on. HDI was introduced by the United Nations Development Program (UNDP) in 1990 and then regularly published in the annual Human Development Report (HDR). The differences of the characteristic of a country will brings up differences in macroeconomic policies, so that the effects of development in the long term will be different [Binder)[4]
HDI is formed by 3 (three) basic dimensions, namely: (1) Decent Living Standards, (2) Knowledge/education, and (3) Long Life and Healthy Living. HDI is an important measuring tool for measuring performance in improving the quality of human life. HDI can also be used to determine the ranking or level of development of a region / country. Because as a measure of government performance, it means that HDI is also strategic data. In addition, the HDI has a function as one of the variables used to determine the allocation of the General Allocation Fund (DAU) [5]. If the level of the population's ability to absorb and manage sources of economic growth is high, related to technology or institutions, the Human Development Index will be high [6].

The speed and status of achievement are two important aspects that need to be considered in order to determine the level of human development progress. Human development in the Special Region of Yogyakarta has increased throughout 2010 to 2018. The Human Development Index in the Special Region of Yogyakarta in 2010 increased from 75.37 to 78.89 in 2018. IPM D.I. Yogyakarta grows by an average of 0.65 percent per year and is at a high level starting from 2010 until the latest data in 2018. The ability of the population to absorb and manage sources of economic growth is determined by the level of Human Development Index of the indicators of aggregate economic progress is economic growth. In Fruin research mentioned that relatively massive variation in the rate of income growth to human development [7]

Economic growth is also an important indicator in conducting an analysis of economic development because economic growth is an indicator of an increase in the production of goods and services. Indonesia's economic growth in 1990-1994 was ranked 9th out of 93 countries, and in 20052011 it was ranked 5. And in 2018 Indonesia was included in the world's top 10 according to the IMF version.

The country's achievement in controlling its economic activities in the short term and in developing its economy in the long term is also reflected by the rate of economic growth. The economic growth of a country is not only supported by an increase in physical capital and the number of workers, but is also determined by an increase in the quality of human capital 
and the use of technology. The economic growth of a country is influenced by the improvement of the quality of human capital (human capital). Quality human capital will have a positive impact on economic growth.

Gross Regional Domestic Product (GRDP) determines the amount of economic growth. Gross Regional Domestic Product (PDRB) is the added value formed from the overall economic activity in an area over a certain period of time. GRDP is presented at constant and current prices. Based on GRDP data, economic growth can be calculated which describes the real increase in the economic capacity of a region.

The development of the GRDP per capita value of DIY during the 2010-2017 period shows an increasing trend. GRDP grew by 3.99 percent per year on average, per capita GRDP increased from Rp. 18.65 million in 2010 to Rp. 24.53 million in 2018. Roughly speaking, that the level of welfare of the DIY population on average has increased. Real per capita GRDP growth has a consistent pattern with economic growth.

In fact, the high Human Development Index in the Special Region of Yogyakarta is not in line with the level of economic growth. The level of economic growth is in the low category indicated by the contribution of DIY PDRB both to the total GRDP of the island of Java and to a total of 34 provinces having a relatively low position. This data can be seen in the graph below:

The economic growth increases the supply of resources needed by human development. The increasing of resources go together with the allocation of human development resources together with increasing resources in the right allocation, for example employment opportunities will have a positive impact for better human development. The economic growth will be driven by human development. Increase spending on human resource detvelopmen and infrastructure is a very important investment in order to improve the quality of human life [8]

Based on the description above, the authors wish to examine the effect of the components of the Human Development index, namely life expectancy, average length of schooling and per capita expenditure on economic growth in the Special Region of Yogyakarta in 2009-2018.

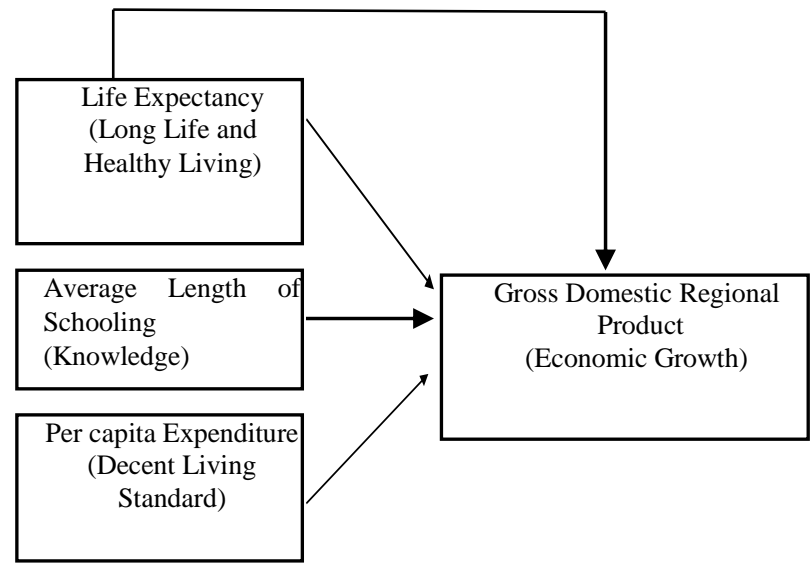

Fig. 1. Theoritical framework.

\section{DATA AND METHOD}

\section{A. Data Source}

The analysis will be carried out using panel data regression analysis. Panel data is a combination of time series data with cross section data. Judging from how to obtain it, this data is classified into secondary data. This data refers to information collected from existing sources. Sources of secondary data are company records or documentation, government publications such as BPS, industry analysis by media, websites, and the internet. In terms of its nature, the data used here is quantitative data, namely data in the form of numbers.

\section{B. Method}

Operational Definition and Variable Measurement

Operational definition of each free variable which is used in this research is as follow,

The Life Expectancy (LE). The Life Expectancy is the average of estimated number of years that can be taken by a person during his life. The life expectancy which is used in this research is the average of population life expectancy in DIY during 2008 until 2017 measured in years.

The Length Average of Schooling (LAS). The length average of schooling is the number of years spent by the population those aged 15 years and over to take all types of formal education that ever taken or being taken. The length average of schooling which is used in this research is the length average of schooling of population those aged 15 years and over according to district or cities in DIY during 2009 until 2018 measured in years.

Per capita Expenditure (PE). Per capita expenditure (PP) is the cost incurred for the consumption of all household members. Per capita expenditure which is used in this research is expenses incurred for the consumption of all household members in district or cities in DIY during 2008 until 2017measured in rupiahs.

Panel Regression Analysis Method To determine the extent of the influence of Life Expectancy, Average Length of 
Schooling, and Expenditure per capita on Economic Growth in DIY from 2009 to 2018

The model equation used in this study is as follows: GROWTH OFIT $=\beta 0+\beta 1$ AHHit $+\beta 2$ RLSit $+\beta 3$ PPit $+\varepsilon$ it (1)

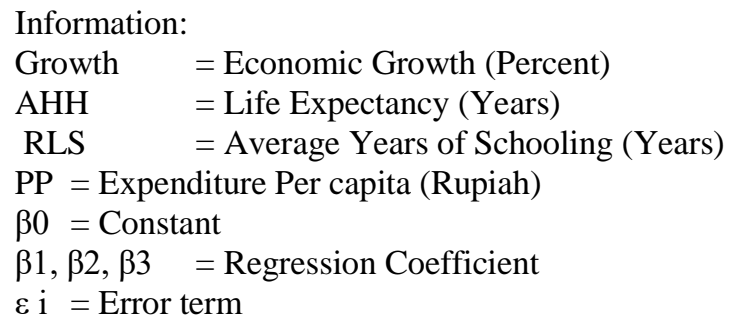

\section{RESULT AND DISCUSSION}

\section{A.Panel Data Analysis}

In this study, the analytical tool used is a panel data linear regression analysis tool using the statistical program Eviews 9. The results of data processing presented here are considered to be the best estimation results because they meet the criteria of economic theory, statistics and econometrics. This estimation result is expected to be able to answer the hypothesis proposed in this study. The results of the multiple regression estimation are used to test the effect of each independent variable (x) on the dependent variable (y) with a partial test. To test the effect of the independent variable $(\mathrm{x})$ on the dependent variable $(\mathrm{y})$ together with a simultaneous test. The coefficient of determination (R2) is used to test the ability of the variable (x) to the dependent variable $(y)$.

The model used in this research is the Common Effect model after testing the model specifications. The estimation results of the panel data regression model obtained are as follows:

Table $1 \quad$ Model Estimation Results

\begin{tabular}{|c|c|c|c|}
\hline Variable & Coefficient & t-statistic & Prob \\
\hline C & 10.01741 & 1.677391 & 0.0002 \\
\hline AHH & -0.089563 & -1.085720 & 0.2833 \\
\hline RLS & 0.193527 & 4.557765 & 0.0000 \\
\hline PP & 1.015205 & 2.458591 & 0.0078 \\
\hline
\end{tabular}

Source: Results of Data Processing

Based on the results of data processing with the Common

Effect model, the following equation is obtained:

GROWTH: $10.01741-0.089563$ AHHit +0.193527 RLS

it $+1.015205 \mathrm{PP}$ it $+\varepsilon$ it

The constant coefficient is 10.01741 based on the regression equation above means, if the average length of schooling, life expectancy, per capita expenditure is 0 , then the value of economic growth is 10.01741. The life expectancy coefficient value is -0.089563 , indicating that every change in the Life Expectancy Number variable is 1 unit, then economic growth will change by 0.089563 units from the Life Expectancy Rate.

The coefficient value of the average length of schooling variable is 0.193527 , indicating that each change in the variable average length of schooling is one unit, then economic growth will change by 0.193527 from the average length of schooling. The value of the Per Capita Expenditure Coefficient is 1.015205 , meaning that every change in the increase in the Per Capita Expenditure variable by one unit, then the economic growth will change to increase by 1.015205 units of Per Capita Expenditure. The quality of human resources as seen from the Life Expectancy Rate (AHH) has a negative effect on economic growth, the average length of schooling (RLS) has a positive effect on economic growth, and per capita expenditure has a positive effect on it. growth. Economy.

\section{Life Expectancy}

Based on panel data analysis that was already used by using the Common Effect model shows that the variable life expectancy is partially influential not significant on the Economic Growth of DIY.

The results of this research are in line with the results of research conducted by [9] in the province of Yogyakarta. This is thought to be due to the high number of life expectancy, but not matched by an increase in skills. This will in fact become a burden for regional development. In addition, it is also due to the lack of job opportunities for the elderly population. It means that their productivitiy level is low.

The results of this research are in accordance with a report by the Central Bureau of Statistics which states that the dependency ratio of the DIY population in 2010 was recorded at 45.9 percent. It means that every 100 people of productive age bear around 46 haven't been productive and unproductive people. This figure is higher than in 2000 which was 44.7 percent. The higher the dependency ratio, the higher the burden that must be borne by the productive age population.

\section{Average length of schooling}

Based on the test results shows that the variable average length of school partially has a significant effect on the Economic Growth of DIY. This is in line with previous research that education is an indicator in determining the quality of human resources. The average length of schooling provides an overview of the level of public knowledge in taking the educational path which in turn will increase productivity through the skills possessed by the workforce. The higher a person's education level and the longer someone goes to school, the knowledge and skills they have will increase so that it will encourage an increase in one's productivity

The increase of the productivity, preceded by the increase in the skills possessed by the workforce, is the outcome of developing human quality. The level of public knowledge in taking the educational path is described by the average length of schooling. The higher a person's education level and the longer someone goes to school, the knowledge and skills they have will increase so that it will encourage the increase in one's productivity [10].

The level of knowledge and skills that workers acquire through education, training and experience is part of the economic concept, namely human capital. This human capital, namely education, training and experience even though it is abstract, plays a very important role in increasing the ability to produce goods and services in an area which will then encourage an increase in economic growth [11]. 
Education plays a major role in building the capacity of a country to absorb and adopt modern technology and to develop the ability to achieve sustainable growth and development. It is a knowledgeable society that is able to take advantage of technological developments. Advanced technology is an important factor in economic development and growth. The existence of technology will drive productivity and efficiency in the production process. Companies and or the production process will be more efficient and effective because they will get a greater output with the same resources, or also because they employ workers with higher productivity. Thus, the company will be better able to provide higher remuneration to workers, due to an increase in profit margins or an increase in the efficiency of the production process. Thus, someone who has high productivity will get better welfare, which can be shown through an increase in his income [12] and [13]. It is mentioned that there are so many paradox about the relationship between the human development index and other variables [14].

\section{Per Capita Expenditure}

The results of t-test linear regression analysis show that the variable per capita expenditure partially has a significant positive effect on the economic growth of districts / cities in the province of Yogyakarta. Per capita expenditure is one of the achievements of human development in realizing a decent life in relation to real per capita consumption. The purchasing power of the community towards a number of basic needs as seen from the average amount of per capita consumption is an income approach that represents the achievement of development for a decent life. The level of welfare is said to increase if there is an increase in real per capita consumption, that is, the increase in nominal household expenditure is higher than the inflation rate in the same period. If per capita consumption increases, demand will also increase so that production will also increase. If production capacity increases, national income and economic growth will increase if public expenditure increases compared to before [15]. It is in line with Eren's research results that gross domestic product per capita affected the development rate. The growth of development will increased the public purchasing power which will ultimately improve the quality of education and health which means increasing the Human Development Index [16] and [17].

\section{CONCLUSION}

Life expectancy index in DIY is high in one side and range of economic growth is low in other side is understandable considering that the life expectancy index has no significant effect on the economic growth rate.

Average length of schooling and per capita expenditure have a positive effect and economically viable life will give a positive influence on the economic performance of a region, including DIY.

\section{ACKNOWLEDGMENT}

Our research was supported by Janabadra University through Institute for Research and Community Service (LP3M) which has funded this research.
A preliminary version of this paper was presented at the 3rd ICOBAME (International Conference on Banking, Accounting, Management and Economics (ICOBAME, 2020). Author greatest appreciation also goes to dean of the Faculty of Economics and Business and vice dean one which has facilitated researcher in full to participate in this seminar.

The authors are grateful to anonymous reviewers for their helpful suggestions to improve this research.

\section{REFERENCES}

[1] Gustav Ranis and Franis Stewart, " Economic Growth and Human Development", World Development, Vol. 28, No.2, pp.197-219, 2000

[2] Fruin, M., Peneva, D., \& Ram, R. (2013). Income Elasticity of Human Development in ASEAN Countries. The Empirical Econometrics and Quantitative Economics Letters. Vol. 2 (4): 13-20.

[3] M.L. Jhingan, The Economic of Development and Planning, Fourty Revised and Enlarged Edition 2011, Vrinda Publication (p) LTD

[4] Binder, M., \& Georgios, G. (2011). Determinant of Human Development: Capturing the Role of Institutions. CESIFo Working Paper Series No. 3397.

[5] Central Bureau Statistics, Indeks Pembangunan Manusia Daerah Istimewa Yogyakarta 2019. Yogyakarta.

[6] Barata, Aloysius Gunadi. 2002. "Pembangunan Manusia dan Kinerja Ekonomi Regional di Indonesia "Jurnal Ekonomi Pembangunan, Vol.7 No.2, hal 113-122.

[7] Çaglayan-Akay, E., \& Van, M.H. (2017). Determinant of the Levels of Development Based on the Human Development Index: Bayesian Ordered Probit Model. International Journal of Economics and Financial Issues. Vol. 7 (5): 425-431.

[8] Baseri, B., \& Kia, A.F. (2008). The Analysis of Factors Affecting Human Development Index in Zanjan Province. Quarterly Journal of Economic Research and Policies. Vol. 16 (47): 5-23.

[9] Rian, Rosalina, Josep (2019). Pengaruh Angka Harapan Hidup, Tingkat Pendidikan Dan Pengeluaran Perkapita Terhadap Pertumbuhan Ekonomi di Sulawesi Utara Pada Tahun 2003-2017. Jurnal Berkala Ilmiah Efisiensi. Vol.19. No. 01. Fakultas Ekonomi dan Bisnis. Universitas Sam Ratulangi, Manado.

[10] Subri, Mulyadi, Ekonomi Sumber Daya Manusia. Jakarta: Rajawali pers, 2014.

[11] Rahardjo Adisasmita, Teori-Teori Pembangunan Ekonomi, Pertumbuhan Ekonomi dan Pertumbuhan Wilayah, cetakan pertama, Graha Ilmu, Yogyakarta, 2013.

[12] Todaro, Michael.P. dan Stephen C. Smith (2013). Pembangunan Ekonomi Di Dunia Ketiga. Edisi Kesebelas. Erlangga, Jakarta

[13] Gustav Ranis and Franis Stewart, " Economic Growth and Human Development", World Development, Vol. 28, No.2, pp.197-219, 2000

[14] David G. Blanchflower, Andrew J. Oswald, Happiness and the Human Development Index: The Paradox of Australia NBER Working Paper No. 11416 June 2005 JEL No. J2

[15] Çaglayan-Akay, E., \& Van, M.H. (2017). Determinant of the Levels of Development Based on the Human Development Index: Bayesian Ordered Probit Model. International Journal of Economics and Financial Issues. Vol. 7 (5): 425-431.

[16] Eren, M., Çelik, A.K., \& Kubat, A. (2014). Determinant of the Level of Development Based on the Human Development Index: A Comparison of Regression Models for Limited Dependent Variables. Review of European Studies. Vol. 6 (1): 10-23. doi: 10.5539/res. v6n1p10.

[17] Shah, S. (2016). Determinant of Huan Development Index: A CrossCountry Empirical Analysis. Munich Personal RePEc Archive (MRPA) Paper No. 73759. Retrieved from https://mpra.ub.unimuenchen.de/73759/1/MPRA_paper 73759 . pdf 